\begin{tabular}{|c|c|}
\hline \multirow{3}{*}{ 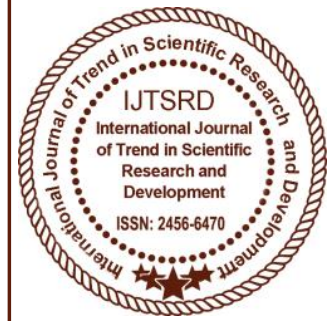 } & $\begin{array}{l}\text { International Journal of Trend in Scientific } \\
\text { Research and Development (IJTSRD) }\end{array}$ \\
\hline & International Open Access Journal \\
\hline & ISSN No: 2456 - 6470 | www.ijtsrd.com | Volume - 2 | Issue - 1 \\
\hline
\end{tabular}

\title{
Antibacterial Activity and Phytochemical Analysis of Euphorbia hirta against Clinical Pathogens
}

\author{
Shanmugam A \\ Department of Biotechnology, \\ St. Michael College of Engg\& Tech, \\ Kalayarkoil, Tamilnadu, India
}

\author{
Subha $\mathbf{S}$ \\ Assistant Professor, Department of Biotechnology, \\ St. Michael College of Engg\& Tech, \\ Kalayarkoil, Tamilnadu, India
}

\author{
Logeshwaran S \\ Department of Biotechnology, \\ St. Michael College of Engg\& Tech, Kalayarkoil, Tamilnadu, India
}

\section{ABSTRACT}

Euphorbia hirta powdered plant material was extracted using two solvents distilled water and methanol. The water extract provide higher yield and also more antibacterial effectiveness than methanol extract used. The well diffusion method was used to determine the antibacterial activity against Escherchia coli, Salmonella typhi, Bacillus subtilis, pseudomonas aeruginosa, Klebsiella pneumoniae. E.hirta plant was investigated for some of their components and antimicrobial activity of their leave extract against bacteria. Phytochemical screening of the crude extracts revealed the presence of tannins, saponins, steroids, flavonoids, terpenoids, and alkaloids.In GCMS analysis, four bioactive phytochemical compounds were identified in the methanolic extract of Euphorbia hirta, the components were identified by comparing their relation indices and mass spectra Fragmentation patterns with those stored on the MSComputer library. This presence of these bioactive constituents has been linked to the antimicrobial activity of the plant material. Dry leaf extracts of $E$. hirta produced the highest zones of inhibition on Salmonella typhi. The herb E. hirta can be used as source of oral drugs to fight infections caused by susceptible bacteria.

Keywords: E.hirta, antibacterial activity, phytochemical analysis, GC-MS.

\section{INTRODUCTION}

Herbal medicine has been used in many parts of the world as a rich tradition for the treatment of a many infectious diseases (Brantner et al., 1994). In developing countries, it is estimated that about $80 \%$ of the population rely on traditional medicine for their primary health care (Matu et al., 2003), because of better cultural acceptability, better compatibility with the human body and fewer side effects. Medicinal herbs have curative properties due to presence of various complex chemical substance of different composition, which are found as secondary plant metabolites in one or more parts of these plants (Kumar et al., 2010). Euphorbia hirta is annual prostrate weed which belongs to family Euphorbiaceae found mostly in India. Euphorbia hirta is commonly known as amman patcharisi by local people. It mainly grows in rainy season. It grows in open grasslands, road sides and pathways. The plant is also widely used in Angola against diarrhea and dysentery, especially amoebic dysentery. In Nigeria extracts or exudates of the plant are used as ear drops and in the treatment of boils, sore and promoting wound healing (Igoli et al., 2005).

This study was undertaken to investigate the phytochemical properties and antibacterial activities of the plant against some economically important bacteria that cause a variety of intestinal and extra intestinal diseases. 


\section{MATERIALS AND METHODS}

\section{Collection and preparation of plant material}

The fresh plant E. hirta was collected around the surroundings of main campus of the St.Michael college of Engineering and Technology, Kalayarkoil, Tamilnadu state, India.The fresh plant was harvested, rinsed with tap water and air dried under shade for 4 days and reduced to coarse powder using pestle and motar and then grinded to fine powder. The powder was stored in an airtight bottle until needed for use.The preparation of extract was done by maceration method. Methanol and water used as solvent. Extraction from fresh and dry leaves of $E$. hirta was done with water and methanol.

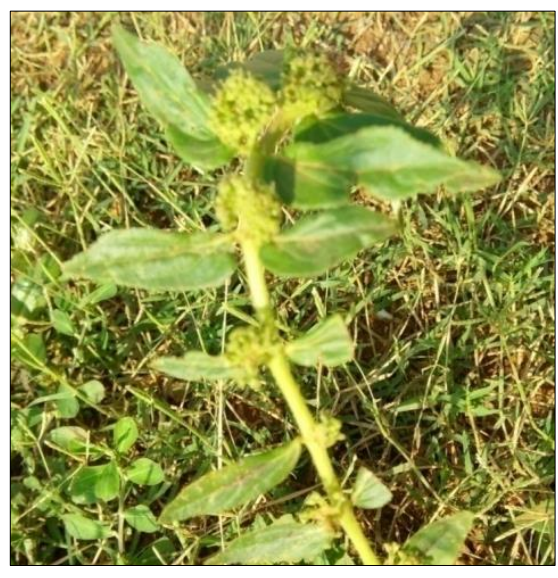

Fig 1:E.hirtaplant

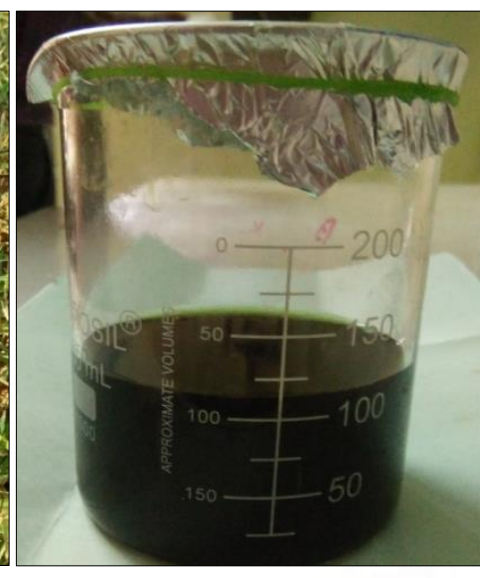

Fig 2: Methanol Extract

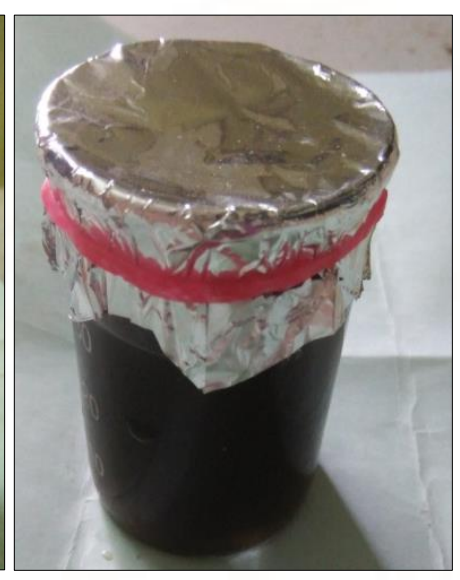

Fig 3: Water Extract
Preliminary phytochemical analysis was done for the both methanol and water extract. Test for tannins, saponins, flavonoids, alkaloids and steroids were done.

GC-MS analysis of the extract was performed using a Perkin-Elmer GC Clarus 500 system. . The relative \% amount of each component was calculated by comparing its average peak area to the total areas, software adopted to handle mass spectra and chromatograms was a Turbomass. Interpretation on mass spectrum GC-MS was conducted using the database of national Institute Standard and technology (NIST) having more than 62,000 patterns.

\section{Antibacterial Activity}

Among five microorganisms one Gram positiveBacillus subtilis while four Gram negative bacteria were Escherichia coli, Salmonella typhi, Klebsiella pneumonia, Pseudomonas aeruginosa. All the cultures maintained on nutrient agar slants at $40^{\circ} \mathrm{c}$. The antibacterial assay activity was performed by agar well diffusion method. For agar well method, about 15-20 ml Muller Hinton agar was poured into sterilized petri plates. After solidification $0.2 \mathrm{ml}$ of broth culture of test microorganism were inoculated in the media separately. $10 \mu \mathrm{l}$ of test compound was introduced into the well. The plates were incubated overnight at $37^{\circ} \mathrm{C}$. Microbial growth was determined by measuring the diameter of zone of inhibition. For each bacterial strain, controls were maintained where pure solvents used instead of the extract. The result was obtained by measuring the zone diameter. The experiment was done three times and the mean values are presented.

\section{RESULTS AND DISCUSSION}

\section{PHYTOCHEMICAL ANALYSIS}

Preliminary phytochemical screening of the crude extract of Euphorbia hirta showed the presence of saponins, tannins, alkaloids, flavonoid, and steroids. Table shows the phytochemical screening of aqueous, methanol, of Euphorbia hirta. Qualitative screening confirms the presence of five compounds support the use of plant in folklore medication.

\begin{tabular}{|l|l|l|}
\hline PHYTO & WATER & METHANOL \\
COMIPOUNDS & EXTRACT & EXTRACT \\
\hline Saponins & + & + \\
\hline Tannins & + & + \\
\hline Flavonoids & + & + \\
\hline Steroids & + & + \\
\hline Alkaloids & + & + \\
\hline
\end{tabular}

Tab 1: Phytochemical composition of water, methanol of E.hirta 


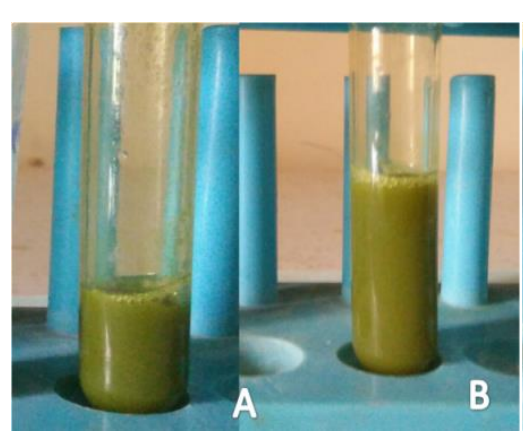

Fig 4: Test for Saponins

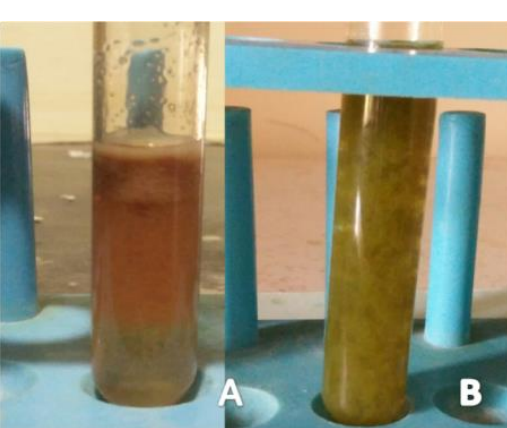

Fig 5: Test for Tannins

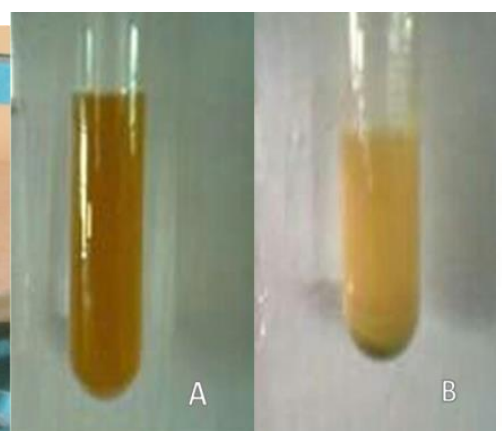

Fig 6: Test For Steroids

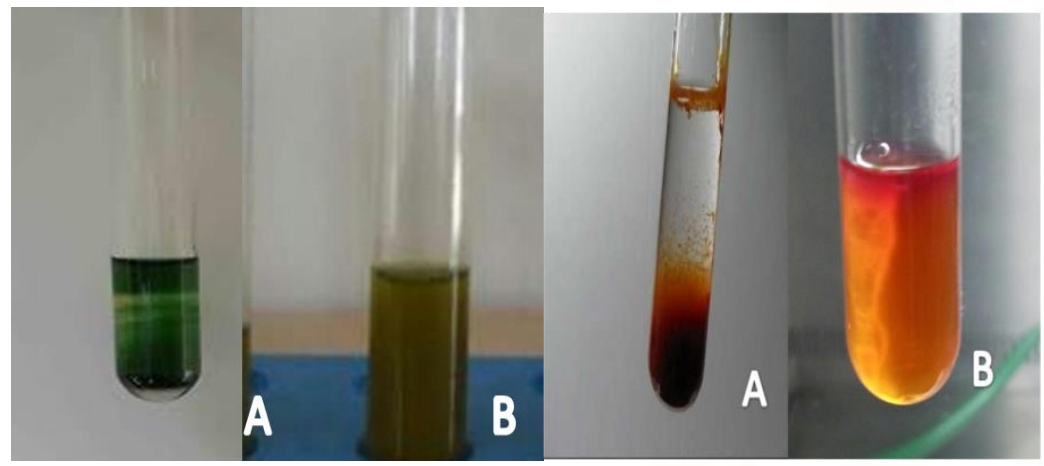

A - Methanolextract, B- water extract

Fig 7: Test for Flavanoids

Fig 8: Test For Alkaloids

\section{GC-MS ANALYSIS}

The methanolic leaf extract of Euphorbia hirta was studied by GC-MS. There are 4 compounds identified using this technique. Among these, phytol, is a major compound because it is act as a skin care agent and anticancer agent .GC-MS chromatogram of the methanol extract of Euphorbia hirtashowed four peaks which indicated the presence of four major phytochemical constituents. The identification of phytochemical compounds is based on the peak area, molecular weight and molecular formula.

\begin{tabular}{|l|l|l|l|l|l|l|}
\hline S. & \multicolumn{1}{|c|}{$\begin{array}{c}\text { Name of } \\
\text { compound }\end{array}$} & $\begin{array}{l}\text { RT } \\
(\mathrm{min})\end{array}$ & $\begin{array}{l}\text { Peak } \\
\text { Area } \%)\end{array}$ & $\begin{array}{l}\text { \% of } \\
\text { equal }\end{array}$ & $\begin{array}{l}\text { Molecular } \\
\text { Weight }\end{array}$ & Molecular \\
\hline 1 & Azulene & 6.021 & 2.98 & 93 & 128.17 & $\mathrm{C}_{10} \mathrm{H}_{8}$ \\
\hline 2 & $\begin{array}{l}\text { 2-propenoic acid, } \\
\text { 3-phenyl }\end{array}$ & 9.038 & 6.20 & 97 & 148.0524 & $\mathrm{C}_{9} \mathrm{H}_{8} \mathrm{O}_{2}$ \\
\hline 3 & $\begin{array}{l}\text { Phytol } \\
4\end{array}$ & 16.441 & 3.28 & 64 & 296.53 & $\mathrm{C}_{20} \mathrm{H}_{40} \mathrm{O}$ \\
\hline & \begin{tabular}{l} 
Bis(2-ethylhexyl) \\
\hline
\end{tabular} & 20.091 & 87.54 & 91 & 390.56 & $\mathrm{C}_{24} \mathrm{H}_{38} \mathrm{O}_{4}$ \\
\hline
\end{tabular}

Tab 2: Phytocompounds identified in the leaf methanol extract of E.hirta 
ALS V1a1 : 4 Sample Multip11ar: 1

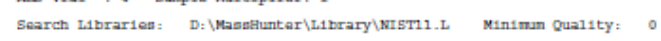

Unknown Spectrum:
Intagration Evente:

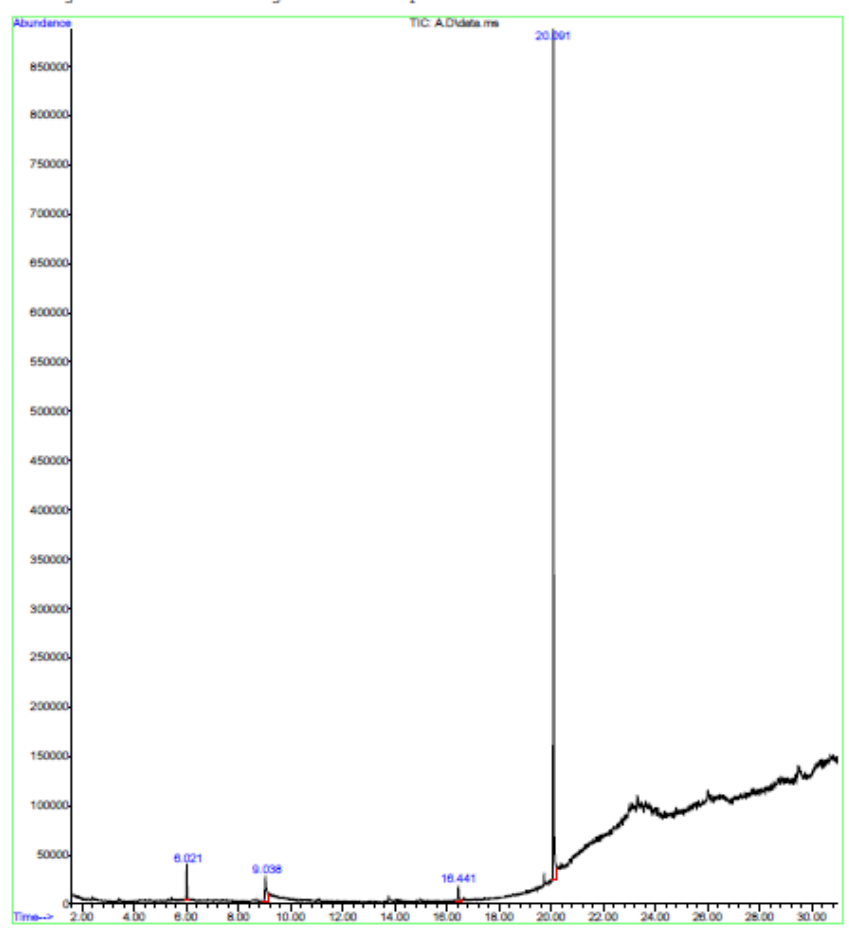

Fig 9: GC-MS chromatogram of methanolic extract of leave of E.hirta

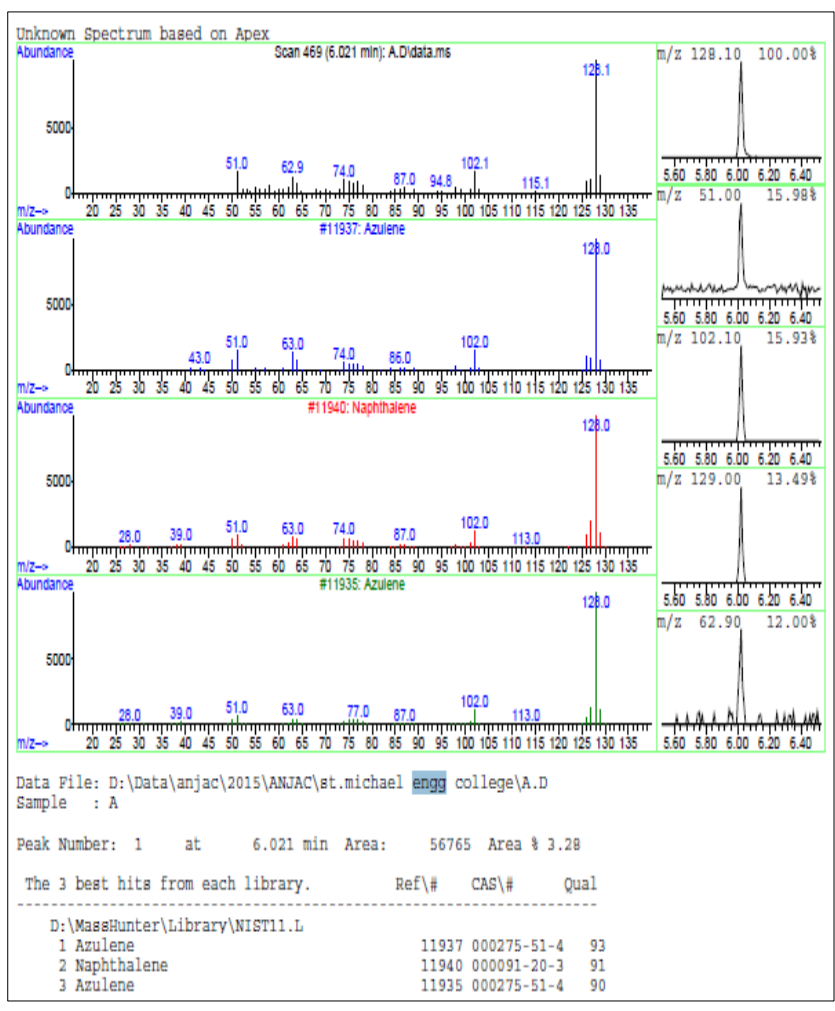

Fig 10: Mass spectrum of azulene

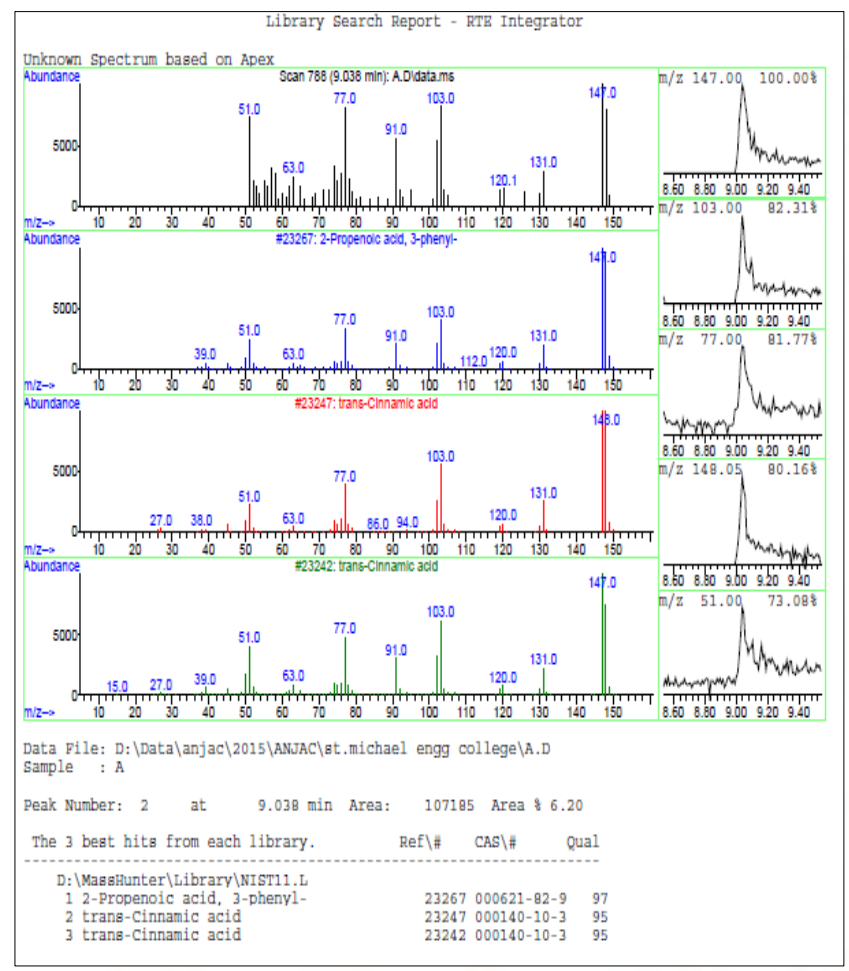

Fig 11: Mass spectrum of 2-propenoic acid, 3phenyl-

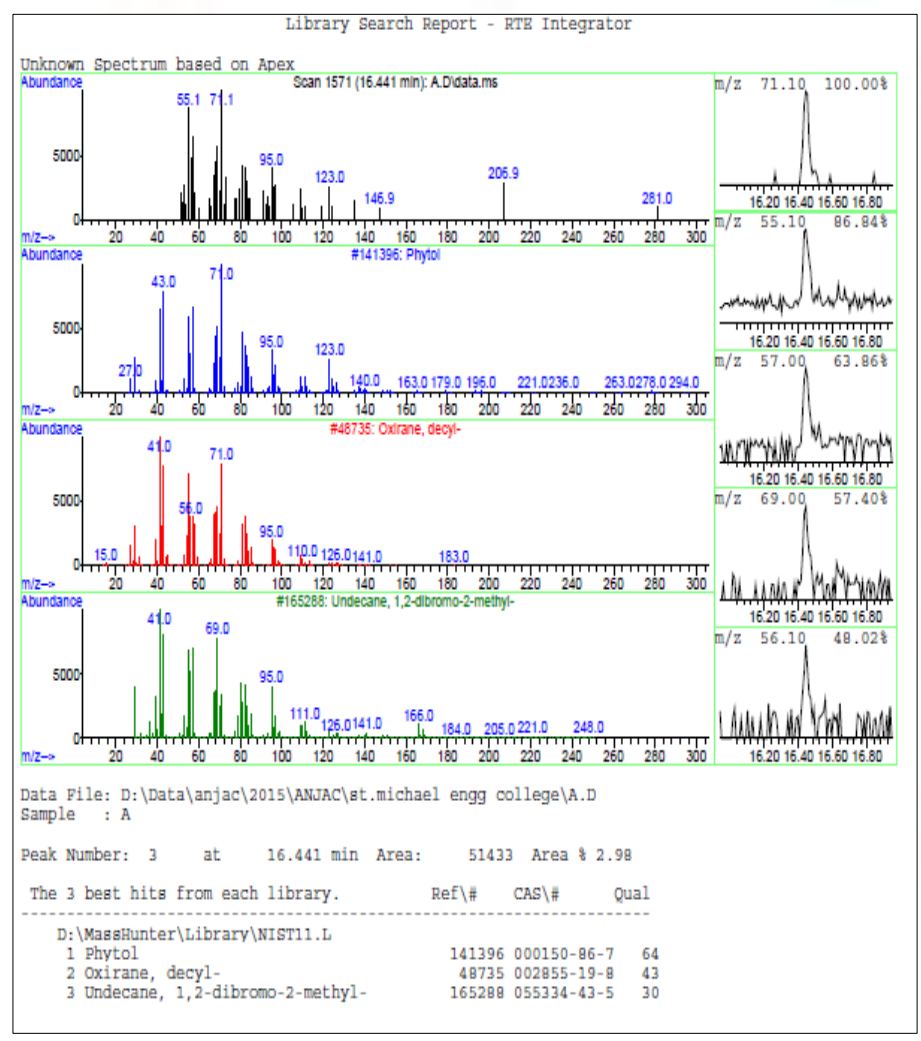

Fig 12: Mass spectrum of phytol 


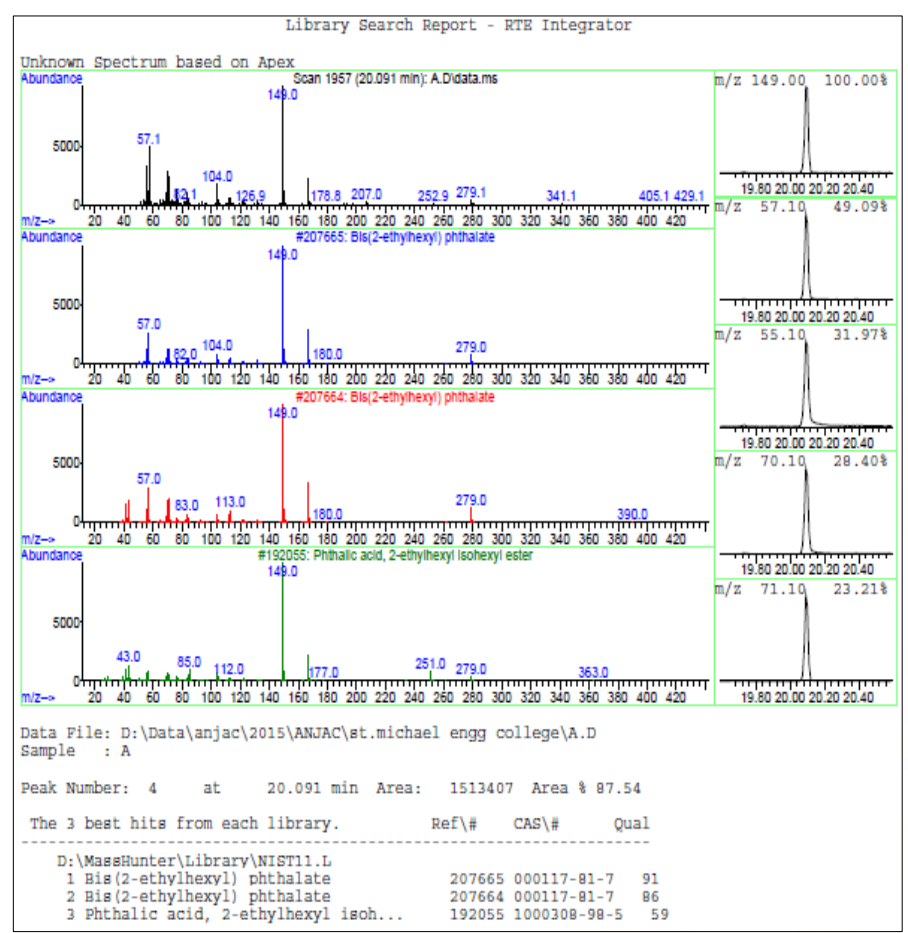

Fig 13:Mass spectrum of Bis (2-ethylhexyl)

\section{ANTIBACTERIAL ACTIVITY}

The antimicrobial activities of E. hirta were assessed using the agar well diffusion method. All the pathogens used in this study were susceptible to both methanol and aqueous extracts of dry leaf of Euphorbia hirta.

The results indicated that at $20 \mu \mathrm{l} / \mathrm{ml}$, methanol extracts of the leaf produced the highest significant zone of inhibition $(11.67 \mathrm{~mm})$ on S.typhi while the least zone of inhibition was observed on P.aeruginosa with an average value of $6.0 \mathrm{~mm}$. Similarly, the effect of the water extracts of the leaf on K.pneumoniae produced the least significant zone of inhibition. However, the highest effect was shown on S.typhi with mean values range is $10.12 \mathrm{~mm}$.

\begin{tabular}{|c|c|c|c|}
\hline \multirow[t]{2}{*}{ ORGANISMS } & \multirow{2}{*}{$\begin{array}{l}\text { CONCENTRATIONS } \\
(\mu \mathrm{l} / \mathrm{ml})\end{array}$} & \multicolumn{2}{|c|}{$\begin{array}{l}\text { ZONEOF INHIBITION } \\
\text { DIAMETER }(\mathrm{mm})\end{array}$} \\
\hline & & $\begin{array}{l}\text { Methanol } \\
\text { extract }\end{array}$ & $\begin{array}{l}\text { Water } \\
\text { extract }\end{array}$ \\
\hline E.coli & 20 & 8.4 & 6.6 \\
\hline S.typhi & 20 & 11.67 & 10.12 \\
\hline B.subtilis & 20 & 7.2 & 5.3 \\
\hline K.pneumoniae & 20 & 7 & 5 \\
\hline P.aeruginosa & 20 & 6 & 5.7 \\
\hline
\end{tabular}




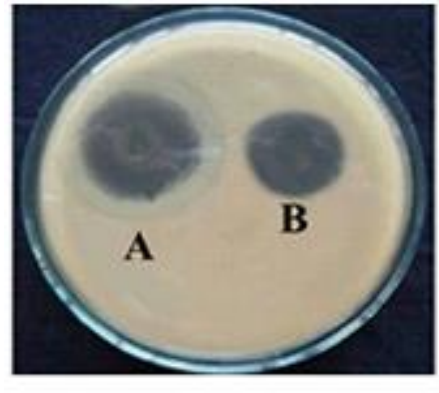

Fig 14: E.coli

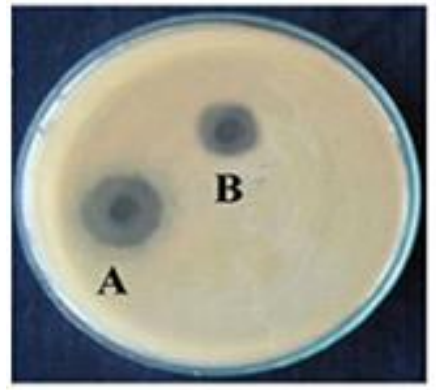

Fig 15: S.typhi

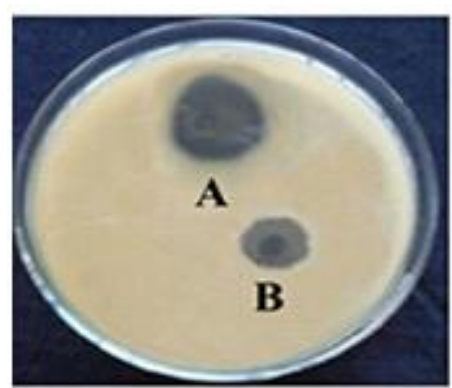

Fig 16:B.subtilis

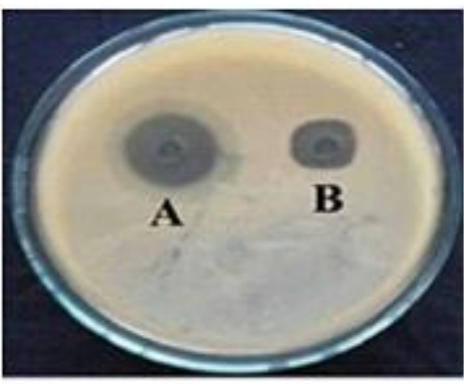

Fig 17: K.pneumoniae

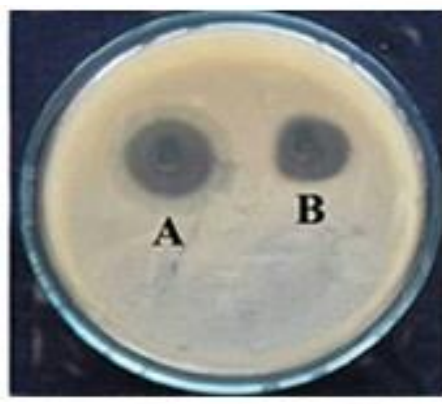

Fig 18: P.aeruginosa

\section{CONCLUSION}

The Euphorbia hirta plant showed antibacterial effect on common pathogen of human. Euphorbia hirta was found to contain some bioactive compounds with pronounced antibacterial activities, further Phytochemical and Pharmacological studies will be needed to isolate the active constituents and evaluate the antimicrobial activities against a wide range of microbial pathogens.

\section{REFERENCE}

1) Abu-Sayeed, M., Ali, M.A., Bhattacharjee, P.K., Islam, A., Astaq, G.R.M., Khan, M. and Yeasmin, S., 2005. Biological evaluation of extracts and triterpenoids of Euphorbia hirta. Pakistan Journal of Scientific and Industrial Research, 48(2), p.122.

2) Adedapo, A.A., Shabi, O.O. and Adedokun, O.A., 2005. Anthelmintic efficacy of the aqueous crude extract of Euphorbia hirta Linn in Nigerian dogs. Veterinarski arhiv, 75(1), pp.39-47.

3) Akinpelu, D.A. and Onakoya, T.M., 2006. Antimicrobial activities of medicinal plants used in folklore remedies in south-western. African Journal of Biotechnology, 5(11).

4) Akujobi, C., Anyanwu, B.N., Onyeze, C. and Ibekwe, V.I., 2004. Antibacterial activities and preliminary phytochemical screening of four medicinal plants. J. Appl. Sci, 7(3), pp.4328-4338.

5) Alam, N.H., Faruque, A.S.G., Dewan, N., Sarker, S.A. and Fuchs, G.J., 2001. Characteristics of children hospitalized with severe dehydration and persistent diarrhoea in Bangladesh. Journal of Health, Population and Nutrition, pp.18-24.

6) Brantner, A. and Grein, E., 1994. Antibacterial activity of plant extracts used externally in traditional medicine. Journal of ethnopharmacology, 44(1), pp.35-40. Burkill, H.M., 1994. The useful plants of west tropical Africa. Volume 2: Families EI (No. Edn 2). Royal Botanic Gardens.

7) C.Azhagumurugan and M.K. Rajan(2014) GC-MS Analysis of Phytochemical Constituents and Nematicidal Activities of Leaf Extract of Magilam, Mimusops elengi World Journal of Zoology 9 (4): 239-243,

8) Carter, S. \& Radcliffe-Smith, A., 1988 Euphorbiaceae (part-2). In: Polhill, R.M (Editor). flora of East Africa. A.A. Balkema, Rotterdam, Netherlands. PP.409-597.

9) Chika C. Ogueke, Jude N. Ogbulie , Ifeanyi C. Okoli And Beatrice N Anyanwu Antibacterial 
Activities And Toxicological Potentials Of Crude Ethanolic Extracts Of Euphorbia hirta Journal of American Science, 3(3), 2007.

10) Chowdhury, S.R., Thungapathra, M., Ramamurthy, T., Nair, G.B. and Ghosh, A., 2003. Class I integrons and SXT elements in El Tor strains isolated before and after 1992 Vibrio cholerae O139 outbreak, Calcutta, India. Emerging infectious diseases, 9(4), pp.500-2.

11) Duke, J.A. and Ayensu, E.S., 1985. Medicinal plants of China (Vol. 2). Reference Publications.

12) El-Mahmood AM, Ameh JM (2007). In-vitro antibacterial activity of Parkia biglobosa (Jacq) root, bark extract against some microorganisms associated with Urinary tract infections. Afr. J.Biotechnol. 6(11): 195-200.

13) Falodun A, Okunrobe LO, Uzoamaka N (2006). Phytochemical screening and anti- inflammatory evaluation of methanolic and aqueous extracts of Euphorbia heterophylla Linn9Euphorbiaceae). Afr. J. Biotechnol. 5(6):529-531

14) Grover, J.K., Yadav, S. and Vats, V., 2002. Medicinal plants of India with anti-diabetic potential. Journal of ethnopharmacology, 81(1), pp.81-100.

15) Igoli, J. O., Ogaji, T. A., Tor-Anyiin and Igoli, N. P. (2005). Traditional Medicine Pactice Amongst the Igede People of Nigeria. Afr. J. Trad. CAM. $2(2) ; 134-152$.

16) Igwe K. K, Madubuike A.J, Akomas S.C , Otuokere I. E.Ukwueze C. S. Studies of the medicinal plant Euphorbia hirta methanol leaf extract phytocomponents by GCMS analysis International journal of scientific and technical research in engineering (IJSTRE) www.ijstre.com Volume 1 Issue 4 || July 2016.

17) Kirtikar, K. R. and Basu, B. D.(1991). Indian Medicinal Plants, Periodical Experts Books Agency, 2nd edition, vol. 3, New Delhi.

18) Kumar D, Malhotra R, Kumar S., (2010). Euphorbia hirta: Its chemistry, traditional and medicinal uses, and pharmacological activities. Phcog Rev; 4:58-61.
19) Kumar, O.A., Naidu, L.M. and Rao, K.R., 2010. Antibacterial evaluation of snake weed (Euphorbia hirta L.). Journal of Phytology, 2(3).

20) Matu, E.N and Van Staden J. (2003). Antibacterial and anti-inflammatory activities of some plants used for medicinal purposes in Kenya. J. Ethanopharmacol., 87(1): 35-41.

21) Mordi RM, Erah PO (2006). Susceptibility of common urinary tract isolates to the commonly used antibiotics in a tertiary hospital in southern Nigeria. Afr.J. Biotechnol. 5(11):1067-1071Lino A, Deogracious O (2006)

22).Pepato, M.T., Mori, D.M., Baviera, A.M., Harami, J.B., Vendramini, R.C. and Brunetti, I.L., 2005. Fruit of the jambolan tree (Eugenia jambolana Lam.) and experimental diabetes. Journal of Ethnopharmacology, 96(1), pp.43-48.

23) The in-vitroantibacterial activity ofAnnona senegalensis, securidacca, longipendiculata andSteganotaenia araliiacea- Ugandan Medicinal Plants. Afr. Health Sci.6 (1):31-35Akujobi, C., Anyanwu, B. N., Onyeze, C. and Ibekwe, V. I. (2004).

24) Winstanley TG, Limb DL, Egginton R, Hancock F (1997). A $10 \mathrm{~m}$ year survey of the antimicrobial susceptibility of urinary tract isolates in the UK: the microbe based project. J. Antimicrob. Chemother. 40:591-594 